\title{
Reaction of pyrido[2,1-a]isoindole with 1,4-naphtoquinone and study of the product by spectroscopic methods
}

\author{
Tatyana Yegorova, ${ }^{*}$ Bogdan Barnych, Zoia Voitenko \\ Department of Chemistry, Taras Shevchenko National University of Kyiv, Volodymyrska Street, \\ 64/13, Kyiv 01601, Ukraine \\ tve2008@ukr.net
}

Keywords: pyrido[2,1-a]isoindole, naphthoquinone, (2E)-2-[(1,4-dihydroxy-2-naphthyl)(2pyridin-2-ylphenyl)methylene]-4-hydroxynaphthalen-1(2H)-one, [4+2]cycloaddition, spectroscopic methods

Key role of the electronic structure of condensed isoindols on the rearrangement pathway was shown. Influence of the dienophile manifests in the requirement of the cyclic form of the dienophile itself. In the reaction of pyrido[2,1-a]isoindole with naphthoquinone rearrangement product of the first type was obtained and its structure was proven by spectral methods. Products of reactions with naphthoquinone, 4-fluoro-, 2,5-difluorophenylmaleimides were isolated and characterized: (2E)-2[(1,4-dihydroxy-2-naphthyl)(2-pyridin-2-ylphenyl)methylene]-4-hydroxynaphthalen-1(2H)-one, (3E)-1-(4-fluorophenyl)-3-[[1-(4-fluorophenyl)-2,5-dioxopyrrolidin-3-yl](2-pyridin-2ylphenyl)methylene]pyrrolidine-2,5-dione, $\quad(3 E)$-1-(2,4-difluorophenyl)-3-[[1-(2,4-fluorophenyl)2,5-dioxopyrrolidin-3-yl](2-pyridin-2-ylphenyl)methylene]pyrrolidine-2,5-dione.

\section{Introduction}

The study of isoindole derivatives and their chemical properties is an important area of heterocyclic chemistry with a long history of research. As a matter of fact the most typical reaction of $[4+2]$ cycloaddition was extensively studied for the simple isoindole which led to the discovery of criteria for the identification of exo-and endo-adducts. During the pioneering research the hypothesis of isoindole electronic structure was formulated and the possibility of the practical use of isoindole derivatives was discussed [17]. Reaction of [4+2]cycloaddition has been methodically studied in our scientific group over the past few decades. Among other results, we discovered three new rearrangements, each being a unique method of synthesis of the rearranged Michael-DielsAlder adducts (intermediate 7-aza-benzo norbornene) of the first [8], second [9] and third [10] type of condensed isoindoles (Figure 1). It was shown that direction of the rearrangement depends on the electron structure of the condensed isoindoles. For example, introduction of the strong electronwithdrawing substituent into the isoindolobenzimidazole fragment results in the formation of the rearrangement product of the third type, along with the traditional for isoindolo[2,1-a]benzimidazole product of the first type[11]. It should be noted that rearranged products present huge interest for both structural as well as medicinal 
chemistries. In particular, such reactions allow easy introduction of the pyrrolidine-2,5dione fragment. Cyclic imides are an important class of molecules known for their diverse array of bioactivities, which include $\alpha-1 \mathrm{~A}$ adrenergic receptor antagonist, androgen receptor antagonist, anxiolytic, antiviral, antibacterial, anti-inflammatory, and antitumor properties. Moreover, succinimide derivatives exhibit potent hypolipidemic and fungicidal properties [12-16]. 3-Heteryl substituted pyrrolidine-2,5-diones were shown to inhibit the enzyme InhA and thus are potential antituberculosis drug candidates $[17,18]$. unsuccessful, resulting in the formation of only Michael-type adducts without rearrangement [20]. Replacement of the 5membered pyrrolidine-2,5-dione cycle by the less strained 1,4-naphtoquinone in the reaction with isoindolo[2,1-a]quinazoline-5one resulted in the formation of the adduct of third type - 2-[2-(4-hydroxy-1-oxo-1,2dihydro-2-naphtalenilidenmethyl)phenyl]-3methyl-3,4-dihydro-4-quinazolone [19]. Thus, we can state necessity of the cyclic dienophile for the rearrangement to occur, but question of the exact influence of the dienophile still remains. Thus, 1,4-naphtoquinone with isoindolo[2,1-a]quinazoline-5-one resulted in the rearranged adduct of the third type. But would it still form such product in case of

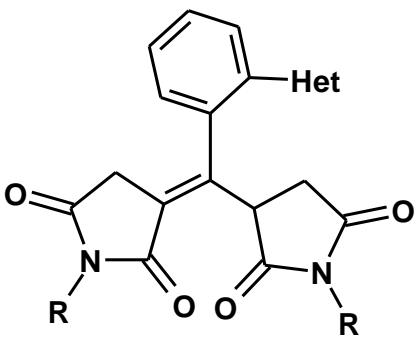

first type

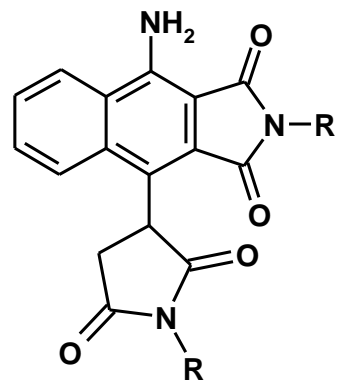

second type

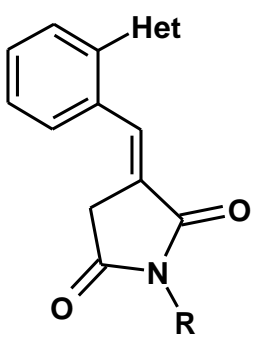

third type

Figure 1. Rearranged Michael-Diels-Alder adducts of the first, second and third type for condensed isoindoles.

Studies of these three types of rearrangements in the cycloaddition reaction of condensed isoindoles were summarized in this thesis [19] and following articles [11, 20]. While it may seem that chemical behavior of the condensed isoindoles is well studied, properties of this system are so inexhaustible that new answers only spawn yet new questions. One of such aspects is influence of the dienophile on the reaction pathway, since all three rearrangements were discovered and studied using condensed isoindoles and maleimides. In other words, is pyrrolidine2,5-dione cycle necessary for the reaction to go this way? It is worth noting that attempts of using non-cyclic dienophiles were other condensed isoindoles? Or reaction way would still be determined by the electronic structure of the condensed isoindoles? This work is dedicated to answer this question.

\section{Results and discussion}

Pyrido[2,1- $a$ ]isoindole, having delocalized general $14 \pi$-electronic system, was chosen for the current study. For this isoindole only rearranged adducts of the first type were known before. In this way, we can avoid duality of the reaction behavior of azoloisoindole system, mentioned in the [11]. Therefore, conclusions from our work could be safely applied to other condensed isoindole systems. Thus, formation of the rearranged 
adduct of the first type in the reaction of pyrido[2,1-a]isoindole with 1,4naphtoquinone would show critical role electronic structure of the condensed isoindoles plays in determining reaction outcome. On the other hand formation of the rearranged adducts of the third type [19], or any other result would show key role of the dienophile.

Reaction between pyrido[2,1a]isoindole $\mathbf{1}$ and 1,4-naphthoquinone $\mathbf{2}$ (Figure 2) was conducted and the reaction product was isolated in pure form. Elemental analysis suggested product being a 1:2 adduct, and thus the rearrangement of the first type was most plausible. We have previously shown that rearrangement of the first type, with maleimides as dienophiles, formed exclusively $E$ isomer adducts, which was proved by X-ray analysis [8, 11, 21]. This process is thermodynamically favored because it involves cleavage of two bridge bonds (C-C and $\mathrm{C}-\mathrm{N}$ ) in a constrained cycle, followed by aromatization of the pyridine ring and formation of an exocyclic double bond. The exclusive formation of the rearranged products with $E$ stereochemistry at exocyclic double bond shows that cleavage of the $\mathrm{C}-\mathrm{C}$ and $\mathrm{C}$ - $\mathrm{N}$ bonds in 7-aza-benzo norbornene undergoes synchronously with formation of the new bonds in the rearranged product. If the rearrangement of the intermediately formed naphthoquinone cycloadduct proceeds via a similar mechanism it should result in the formation of only $\mathrm{E}$ isomer.
We have encountered certain complications during spectral identification of the rearranged product. In the case of rearranged products derived from maleimides their structures can be easily established as structure-defining NMR parameters of pyrrolidine-2,5-dione protons are known [8$11,19,21,22]$. In case of rearranged product formed from the reaction of pyridoisoindole with naphtoquinone only aromatic protons were observed in ${ }^{1} \mathrm{H}$ NMR spectrum. This indicated that tautomeric equilibrium between ketone and enol forms is significantly shifted toward the enol form 4. Additional support for this comes from presence of the strong absorption bands in the IR spectrum at 1200$1300 \mathrm{~cm}^{-1}$ and at $1663 \mathrm{~cm}^{-1}$ with thin structure corresponding to $\mathrm{C}-\mathrm{O}$ oscillations of the phenol and conjugated carbonyl group respectively.

It should be noted, that hindered rotation around single bonds directly attached to the tetrasubstituted alkene lead to the existence of atropodiastereomers in the rearranged products of the first type. Determination of the ratio of atropodiastereomers by ${ }^{1} \mathrm{H} \quad \mathrm{NMR}$ spectroscopy is sometimes complicated due to the signals overlap. We thought that introduction of the fluorine label into dienophile would greatly facilitate this task by allowing us to monitor their ratio by ${ }^{19} \mathrm{~F}$ NMR spectroscopy. 
<smiles>CCCCCc1ccccc1C(=O)CC1c2ccccc2C(=O)CC1c1c2ccccc2c2ccccn12</smiles>

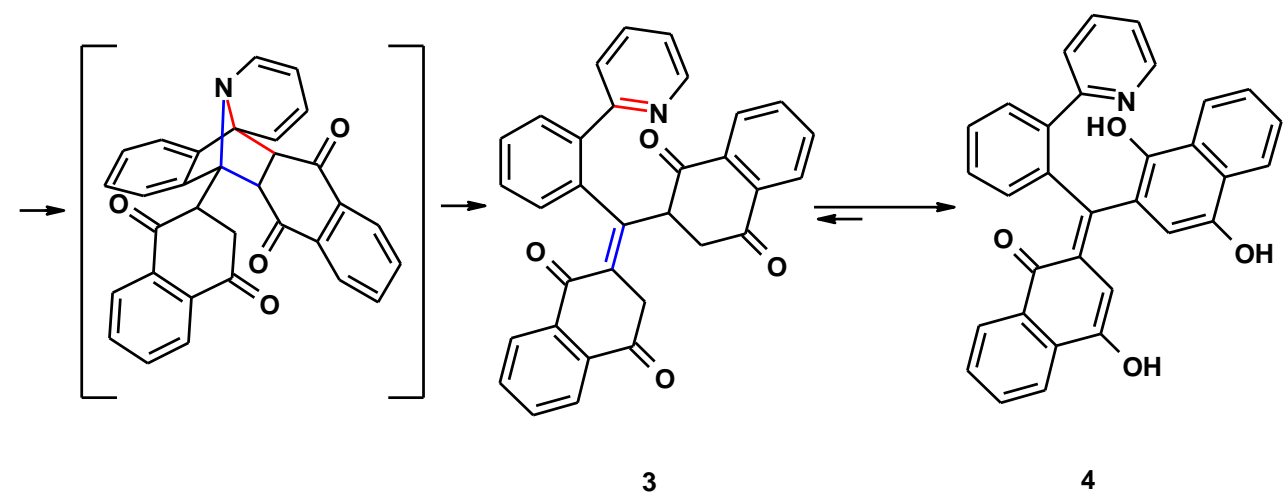

Figure 2. The reaction between pyrido[2,1-a]isoindole and naphthoquinone.

To test this hypothesis 4fluorophenilmaleimide $\mathbf{5 a}$ and 2,4difluorophenilmaleimide $\mathbf{5 b}$ were introduced into the reaction with pyrido[2,1-a]isoindole to give two new rearrangement adducts of the first

(Figure

$3)$.

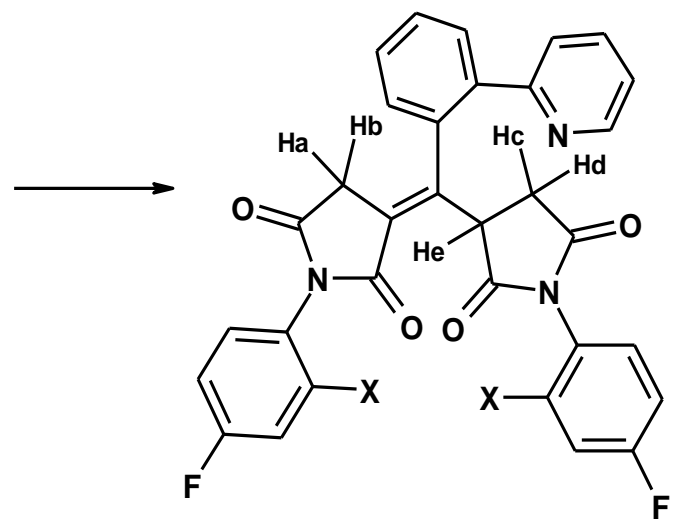

6<smiles>[X]c1cc(F)ccc1N1C(=O)C=CC1=O</smiles>

5 a $X=H, b \quad X=F$

Figure 3. The reaction between pyrido[2,1-a]isoindole and 4-fluoro- and 2,4-difluorophenilmaleimides.

Rearranged products from the reaction with maleimides were identified and characterized by ${ }^{1} \mathrm{H}$ and ${ }^{13} \mathrm{C} \quad \mathrm{NMR}$ spectroscopy.

Analysis of the ${ }^{19} \mathrm{~F}$ NMR spectra showed that peaks corresponding to the starting maleimides and atropodiastereomers are well resolved. Thus, it was shown that the rearranged products $6 \mathbf{a}$ and $\mathbf{6 b}$ were obtained as a mixture of 2 atropodiastereomers in a ratio $1: 2$ and $1: 1$ respectively. Interestingly, monitoring of the reaction between 
pyridoisoindole and maleimide $\mathbf{5 a}$ by ${ }^{19} \mathrm{~F}$ spectroscopy showed that the ratio of atropodiastereomers is always 1:2 and does not depend on conversion, solvent $(\mathrm{EtOH}$ or DCM) or reaction temperature.

\section{Conclusions}

Key role of the electronic structure of the condensed isoindols in the reaction pathway was shown. In case of the reaction between pyrido[2,1- $a$ ]isoindole and naphthoquinone rearrangement adduct of the first type was obtained and its structure was proven by spectral methods. Products of reactions with naphthoquinone, 4-fluoro-, 2,4difluorophenylmaleimides were isolated and characterized: (2E)-2-[(1,4-dihydroxy-2naphthyl)(2-pyridin-2-ylphenyl)methylene]-4hydroxynaphthalen-1(2H)-one, (3E)-1-(4fluorophenyl)-3-[[1-(4-fluorophenyl)-2,5dioxopyrrolidin-3-yl](2-pyridin-2-

ylphenyl)methylene] pyrrolidine-2,5-dione, (3E)-1-(2,4-difluorophenyl)-3-[[1-(2,4-

fluorophenyl)-2,5-dioxopyrrolidin-3-yl](2pyridin-2-ylphenyl)methylene]pyrrolidine2,5-dione.

\section{Experimental part}

${ }^{1} \mathrm{H}$ NMR and ${ }^{13} \mathrm{C}$ NMR were recorded on the Varian VXR-400, ${ }^{19} \mathrm{~F}$ NMR were recorded on the Varian VXR-200 with $\mathrm{C}_{6} \mathrm{~F}_{6}$ as internal standart. IR spectra were recorded on the PerkinElmer Spectrum BX. Elemental analyses were made on the universal analyzer vario MikroCube.

(2E)-2-[(1,4-dihydroxy-2-naphthyl)(2pyridin-2-ylphenyl)methylene ]-4hydroxynaphthalen-1(2H)-one 4.

To a refluxed solution of pyrido[2,1a]isoindole $(0.45 \mathrm{~g} 2.7 \mathrm{mmol})$ in $40 \mathrm{ml}$ of ethanol was added a solution of naphthoquinone $(0.85 \mathrm{~g}, 5.39 \mathrm{mmol})$ in $10 \mathrm{ml}$ of ethanol and the resulting mixture was refluxed for $24 \mathrm{hr}$. Boiling reaction mixture was filtrated, the filtrate was cooled down to r.t. and the precipitated product was collected by filtration. The residue was recrystallized from ethanol.

Crystal solid of the brick color (Yield: $0.26 \mathrm{~g}, 20 \%) .{ }^{1} \mathrm{H}$ NMR $\delta\left(400 \mathrm{MHz}, \mathrm{CDCl}_{3}\right)$ $7.02\left(1 \mathrm{H}, \mathrm{t},{ }^{3} J_{\mathrm{HH}}=6,5 \mathrm{~Hz}\right), 7.14\left(1 \mathrm{H}, \mathrm{t},{ }^{3} J_{\mathrm{HH}}=\right.$ $7.5 \mathrm{~Hz}), \quad 7.21 \quad(1 \mathrm{H}, \quad \mathrm{s}), \quad 7.23-7.24 \quad(1 \mathrm{H}$ $\left.+\mathrm{CDCl}_{3}\right), 7.28(1 \mathrm{H}, \mathrm{s}), 7.46\left(2 \mathrm{H}, \mathrm{t},{ }^{3} J_{\mathrm{HH}}=7.5\right.$ $\mathrm{Hz}), 7.74\left(2 \mathrm{H}, \mathrm{t},{ }^{3} J_{\mathrm{HH}}=7.3 \mathrm{~Hz}\right), 7.78(2 \mathrm{H}, \mathrm{t}$, $\left.{ }^{3} J_{\mathrm{HH}}=7.5 \mathrm{~Hz}\right), 7.84\left(2 \mathrm{H}, \mathrm{d},{ }^{3} J_{\mathrm{HH}}=8.5 \mathrm{~Hz}\right)$, $8.08\left(2 \mathrm{H}, \mathrm{t},{ }^{3} J_{\mathrm{HH}}=8.7 \mathrm{~Hz}\right), 8.17\left(2 \mathrm{H}, \mathrm{t},{ }^{3} J_{\mathrm{HH}}=\right.$ $7.7 \mathrm{~Hz}), 8.49(1 \mathrm{H}, \alpha-\mathrm{CH}$ Py).

${ }^{13} \mathrm{C}$ NMR $\delta(100.7 \mathrm{MHz}$, DMSO-d6) $101.65,108.93,116.03,117.76,118.84$, $120.20, \quad 120.32,122.25,122.86,124.01$, $124.61, \quad 126.62, \quad 126.92, \quad 127.66$, $127.81,128.65, \quad 130.12, \quad 131.07, \quad 132.03$, $133.23, \quad 133.92, \quad 134.96,138.72,139.75$, $141.24,141.51,147.68,148.41,149.67$, $149.92,152.62,183.48$.

IR (KBr) 3429, 3066, 2930, 2858, $1663,1623,1594,1539,1510,1478,1441$, 1391, 1351, 1322, 1285, 1260, 1217, 1115, 1083, 1006, 967, 887, 818, 749, 720, 687, $615,586,492,451,412 \mathrm{~cm}^{-1}$

Analysis (calcd, found)\% C (79.49, 78.26); H (4.38, 3.47); N (2.90, 2.23).

(3E)-1-(4-fluorophenyl)-3-[[1-(4fluorophenyl)-2,5-dioxopyrrolidin-3-yl](2pyridin-2-ylphenyl)methylene]pyrrolidine2,5-dione 6 a.

To a refluxed solution of pyrido[2,1$a$ ]isoindole $(0.2 \mathrm{~g}, 1.2 \mathrm{mmol})$ in $30 \mathrm{ml}$ of ethanol was added a solution of 4fluoromaleimide $(0.46 \mathrm{~g}, 2.4 \mathrm{mmol})$ in $10 \mathrm{ml}$ of ethanol and the resulting solution was refluxed for $12 \mathrm{hr}$. After cooling to r.t. the 
precipitated product was filtrated and recrystallized from the minimal quantity of ethanol.

Grey crystal solid (Yield: $0.23 \mathrm{~g}, 35$ $\%) .{ }^{19} \mathrm{~F}$ NMR $\delta\left(188 \mathrm{MHz}, \mathrm{CDCl}_{3}\right)-113,01$ $(0.67 \mathrm{~F}),-112,60\left(1.33 \mathrm{~F}, \mathrm{t},{ }^{3} J_{\mathrm{HF}}=7.5 \mathrm{~Hz}\right)$.

${ }^{1} \mathrm{H}$ NMR $\delta\left(400 \mathrm{MHz}, \mathrm{CDCl}_{3}\right), 2.73-$ $3.21\left(4 \mathrm{H}\right.$, br m, $\left.\mathrm{H}_{\mathrm{a}}, \mathrm{H}_{\mathrm{b}}, \mathrm{H}_{\mathrm{c}}, \mathrm{H}_{\mathrm{d}}\right), 4.23(0.66 \mathrm{H}$, br s, $\left.\mathrm{H}_{\mathrm{e}}\right), 5.94\left(0.33 \mathrm{H}\right.$, br s, $\left.\mathrm{H}_{\mathrm{e}}\right), 7.13-7.29$ (9H, br m, Ar), 7.47-7.71 (5H, br m, Ar), 7.82 $\left(1 \mathrm{H}, \mathrm{q}, 3 \mathrm{H} \mathrm{Py},{ }^{3} J_{\mathrm{HH}}=7.3 \mathrm{~Hz}\right), 8.57(1 \mathrm{H}, \alpha-$ CH Py).

${ }^{13} \mathrm{C}$ NMR $\delta(100.7 \mathrm{MHz}$, DMSO- $d 6)$ $34.64,39.60,47.12,115.51\left(4 \mathrm{C}, \mathrm{d},{ }^{2} J_{\mathrm{CF}}=21\right.$ Hz) $122.68,123.29,123.78,127.65,128.96$ (br, m), 129.05, 129.13, 129.75, 130.15, $136.66,137.12,137.79,149.18,156.76$, $159.79\left(2 \mathrm{C}, \mathrm{d},{ }^{1} J_{\mathrm{CF}}=245 \mathrm{~Hz}\right), 171.92$, 172.26, 175.34, 175.52 .

IR (KBr) 3451，3070，2930，1768, $1710,1644,1608,1587,1565,1510,1467$, 1427, 1391, 1296, 1278, 1231, 1195, 1148, 1101, 1057, 1021, 988, 959, 941, 912, 883, $839,821,800,760,718,671,643,589,520$, $495,466,423 \mathrm{~cm}^{-1}$

Analysis (calcd, found)\% C (69.94, 69.71); H (3.85, 3.59); N (7.65, 7.06).

(3E)-1-(2,4-difluorophenyl)-3-[[1(2,4-fluorophenyl)-2,5-dioxopyrrolidin-3yl] (2-pyridin-2-

ylphenyl)methylene ]pyrrolidine-2,5-dione $\boldsymbol{6} \boldsymbol{b}$.

To a refluxed solution of pyrido[2,1a] isoindole $(0.2 \mathrm{~g}, 1.2 \mathrm{mmol})$ in $30 \mathrm{ml}$ of ethanol was added a solution of 2,4difluoromaleimide $(0.5 \mathrm{~g}, 2.4 \mathrm{mmol})$ in $10 \mathrm{ml}$ of ethanol and the resulting solution was refluxed for $12 \mathrm{hr}$. After cooling to r.t. the precipitated product was filtrated and recrystallized from the minimal quantity of ethanol.

Grey crystal solid $(0.16 \mathrm{~g}, 23 \%) .{ }^{19} \mathrm{~F}$ NMR $\delta\left(188 \mathrm{MHz}, \mathrm{CDCl}_{3}\right)-107,30$ (2F, m), $114,61(2 \mathrm{~F}, \mathrm{~m})$.

${ }^{1} \mathrm{H}$ NMR $\delta\left(400 \mathrm{MHz}, \mathrm{CDCl}_{3}\right) 2.77-$ $3.23\left(4 \mathrm{H}\right.$, br m, $\left.\mathrm{H}_{\mathrm{a}}, \mathrm{H}_{\mathrm{b}}, \mathrm{H}_{\mathrm{c}}, \mathrm{H}_{\mathrm{d}}\right), 4.23(0.55 \mathrm{H}$, br s, $\left.\mathrm{H}_{\mathrm{e}}\right), 6.23\left(0.45 \mathrm{H}\right.$, br s, $\left.\mathrm{H}_{\mathrm{e}}\right), 6.96(4 \mathrm{H}, \mathrm{br}$ $\mathrm{m}, \mathrm{Ar}), 7.26(4 \mathrm{H}, \mathrm{br} \mathrm{m}, \mathrm{Ar}), 7.61(4 \mathrm{H}, \mathrm{br} \mathrm{m}$, Ar), $7.83\left(1 \mathrm{H}, \mathrm{q}, 3 \mathrm{H} \mathrm{Py},{ }^{3} J_{\mathrm{HH}}=7.0 \mathrm{~Hz}\right), 8.58$ (1H, $\alpha-\mathrm{CH}$ Py).

${ }^{13} \mathrm{C}$ NMR $\delta(100.7 \mathrm{MHz}$, DMSO- $d 6)$ $34.72,39.54,47.29,104.87\left(2 \mathrm{C}, \mathrm{t},{ }^{2} J_{\mathrm{CF}}=21\right.$ $\mathrm{Hz}), 112.06\left(2 \mathrm{C}, \mathrm{d}, \mathrm{br}{ }^{2} J_{\mathrm{CF}}=21 \mathrm{~Hz}\right), 117.29$ (m, br), 122.65, 122.70, 123.12, 127.67, $129.15,129.63,129.69,129.99,131.32(\mathrm{~m}$, br), 134.95, 137.15, 137.99, 149.07, 156.99, $158.38\left(2 \mathrm{C}, \mathrm{d},{ }^{1} J_{\mathrm{CF}}=245 \mathrm{~Hz}\right), 160.88(2 \mathrm{C}, \mathrm{d}$, $\left.{ }^{1} J_{\mathrm{CF}}=245 \mathrm{~Hz}\right), 171.44,174.40,174.44$, 174.51 .

IR (KBr) 3451，3080，2930，1779, $1717,1663,1648,1608,1587,1568,1514$, $1467,1441,1427,1394,1300,1275,1255$, 1227, 1195, 1140, 1101, 1061, 1021, 988, $970,905,887,851,803,760,713,680,665$, $643,611,596,557,503,484,470,452,430$, $408 \mathrm{~cm}^{-1}$

Analysis (calcd, found)\% C (65.64, 65.63); $\mathrm{H}(3.27,2.85) ; \mathrm{N}(7.18,6.58)$.

\section{References}

[1] V.A. Kovtuneko, Z.V. Voitenko, Usp. Khim.,. 1994, 63, 1064.

[2] . K. Speck, T. Magauer, Beilstein J. Org. Chem. 2013, 9, 2048.

[3] J. A. Joule, in M. Sainsbury (Ed.), Rodd's Chemistry of Carbon Compounds, 2nd Edn., Vol. 4, Pt. A, Hardcover, Elsevier, 1997, pp. 557-605. 
[4] K. J. Herd, in R. P. Kreher (Ed.), Metoden der Organischen Chemie (Houben-Weyl), 4nd Edn., Vol E6b1, Georg Thieme Verlag, Stuttgart, 1994, pp. 451-545.

[5] F. S. Babichev, V. A. Kovtunenko, Khimija isoindola (Chemistry of isoindole), Naukova Dumka, Kyiv, 1983.

[6] T. J. Donohoe, Sci. Synthesis, 10, 2001, 653.

[7] R. Bonnett, S. A. North, Adv. Heterocycl. Chem., 29, 1981, 341.

[8] Z.V. Voitenko, O.A. Pokholenko, O.O. Chkarov, O.V. Shishkin, S.V. Shishkina, A. Dall'ava, M. Vedrenne, M. Sanches, Eur. J. Org. Chem., 2001, 1401 .

[9] Z.V. Voitenko, O.A. Pokholenko, O.T. Ilkun, M.R. Maziéres, J.G. Wolf, Comptes Rendus Chimie, 2006, 1482.

[10] Z.V. Voitenko, V.P. Samoilenko, V.A. Kovtunenko, V.Yu. Gurkevich, A.K. Tyltin, M.V. Shcherbakov, O.V. Shishkin, Chem. Heterocycl. Comp. (Translated from Khim. Geterotsikl. Soedin)., 1999, 35, 600.

[11] O. Korolev, T. Yegorova, I. Levkov, V. Malytskyy, O. Shishkin, R. Zubatyuk, G. Palamarchuk, M. Vedrenne, M. Baltas, Z. Voitenko, J. Mol. Struc., 2015, 1084, 177.

[12] H.S. Snyder, Drugs and the Brain; Scientific American Library: New York, 1986.

[13] A.M. Crider, T.M. Kolczynski, K.M.J. Yates, Med. Chem. 1980, 23, 324.

[14] Y. Ando, E. Fuse, W.D. Figg, Clin. Cancer Res. 2002, 8, 1964.

[15] C. Freiberg, H.P. Fischer, N.A. Brunner, Antimicrob. Agents Chemother. 2005, 49, 749.

[16] J.J. Wang, T.Y. Liu, P.H. Yin, C.W. Wu, Y.T. Chern, C.W. Chi, Anticancer Res. 2000, 20 (5A), 3067.
[17] T. Matviiuk, G. Mori, C. Lherbet, F. Rodriguez, M.R. Pasca, M. Gorichko, B. Guidetti, Z. Voitenko, M. Baltas, Eur. J. Med. Chem., 2014, 71, 46.

[18] T. Matviiuk, F. Rodriguez, N. Saffon, S. Mallet-Ladeira, M. Gorichko, A.L. De Jesus Lopes Ribeiro, M.R. Pasca, C. Lherbet, Z. Voitenko, M. Baltas, Eur. J. Med. Chem., 2013, 70, 37.

[19] Z.V. Voitenko Thesis for a Doctors' degree, Chemical sciences, speciality 02.00.03 Organic Chemistry, Kyiv, 2005.

[20] Z.V. Voitenko, O.I. Halaev, V. P. Samoylenko, S.V. Kolotilov, Ch. Lepetit, B. Donnadieu, R. Chauvin, Tetrahedron, 2010, 66, 8214.

[21] Z. Voitenko, V. Lyaskovskyy, J.G. Wolf, J. Jaud, ARKIVOC, 2007, XV, 90.

[22] Z.V. Voitenko, A.A. Pokholenko, O.O. Chkarov, V.A. Kovtunenko, F.S. Babichev, Chem. Het. Comp., 2002, 2, 190. 